\title{
7 \\ Justice and the Judicial Role of the Monastery
}

Beneficence ... is less essential to the existence of society than justice. Society may subsist, though not in the most comfortable state, without beneficence: but the prevalence of injustice must utterly destroy it.

- Sмітн [1759] 2002 II.II 3.3: 86

The judicial position of the monastery in traditional Tibetan society is not well known. The numerous examples given in previous chapters suggest that indeed the monastic authorities had the power to discipline and punish their resident monks. It has furthermore been noted that "the monastic estate was a legal unit." Unknown, however, is how this legal unit functioned. To what extent were monasteries autonomous in terms of jurisdiction? Speaking of Buddhist monasticism tout court, it has been suggested that "monks are under no authority but their own order" and that "[ $t$ ]heoretically, the monk is no longer subject to the secular authority and answers only to the Buddhist code of discipline, the Vinaya." ${ }^{3}$ However, there is historical evidence that monks in Tibet were occasionally subject to state law. ${ }^{4}$ My informants, in answering the question as to how the monastic guidelines relate to the secular law, are unanimous in their understanding that the monastic guidelines - and thus the behavior of monks - need to be in accord with the law of the land. A scholar monk from Kirti, Rendo Senggé, responded in the following way:

Generally speaking the monastic guidelines fall under the state law: their contents can never be in contradiction with the general law. In old Tibet there was never any such problem. Nowadays it is quite difficult, because we are focused on education, our own system of education. China does not want the monks to study, they want them to stay put and just pray. ${ }^{5}$ 
The issue referred to here is that of the minimum age set by the Chinese authorities to enter the monastery. It is currently higher than is customary or ideal in Tibetan monasteries and this policy is seen as a serious limitation to the education of monks. This presents a large number of monks in contemporary Tibet with an ethical problem, although on the whole, prioritizing is not difficult: the monastic customs are seen as more important than state policy.

If in pre-modern Tibet monastic estates were indeed legal units, could monasteries try and punish laypeople who committed crimes within their jurisdiction? And, for what "crimes" would a monk be subjected to the secular authorities? How sharp was the distinction between secular and monastic law? These are crucial questions, the answers to which are important to determine the overall position of the monastery, and by extension, monastic Buddhism in Tibetan society.

According to Ellingson, chayik were based on "secular" law codes. ${ }^{6}$ A preliminary comparison of the monastic guidelines and the extant legal codes of Tibet indeed indicates that-in particular, terminologically and linguistically-there are striking similarities between the two genres. However, it appears more likely that these similarities are due to the fact that the authors of the two types of texts were often one and the same, and because, as indicated in the previous chapter, the educated few were almost always monastically schooled. There are even instances of law codes that were explicitly based on monastic guidelines, the current code of conduct issued by the Bhutanese state a case in point.7 The question of how exactly monastic guidelines and legal documents are related requires further investigation, ${ }^{8}$ but this chapter focuses on the ways in which the chayik inform us about monastic legal policies and practices, and the Buddhist sensibilities that may be embedded within.

Such a discussion belies larger issues, such as the relation between Buddhism and the execution of justice. According to French, the two are intimately related: "Mind training and inner morality are also the center of the legal system for Tibetan Buddhists because it is the afflicted mind that creates the conflict and unhappiness that brings about legal disputes." She argues in her anthropological study of the legal system in traditional Tibet that ultimately "[a]ll laws were understood as religious." ${ }^{10}$ And following that, all punishment "was meant to promote a return to inner morality." ${ }^{11}$ This, whether it concerns secular or monastic legal policies, seems highly questionable.

The many punishments enumerated in the monastic guidelines suggest that the aim of such measures is only to a very limited extent to purify negative karma. Rather-comparable to legal systems all over the world-the primary goal of punitive measures and rules is to keep the peace and maintain a balance. Authors of regulations were not directly concerned with the individual's karma, mind training, or morality, but with protecting the monastery, the Sangha, and thus the Dharma against the threat of lawlessness. The monastic guidelines then, when 
they note the importance of adhering to the rules, do entreat the monks to heed their vows, but at the same time in the practical application of the rules (or monastic laws), karma, mindfulness, and morality play only a minor role.

\section{THE JUDICIAL POSITION AND JURISDICTION OF MONKS AND MONASTERIES}

According to a narrative found in the Mülasarvāstivāda vinaya, the ideal situation is a separation of secular and religious law. The king must acknowledge that lay law does not apply to the monks and that, obviously, monastic law does not apply to the laymen..$^{12}$ In the Tibetan case, however, it is obvious that this strict division was seen as neither practical nor desirable. However, clear distinctions were made. Early on in the history of Tibetan monasticism, monks were granted a legal status distinct from that of laypeople. The sixteenth-century work "A Scholar's Feast,"13 citing an edict purported to have been issued by the ruler Tridè Songtsen (Khri lde srong btsan, a.k.a. Sad na legs, r. c.8oo-815), records this position of privilege: "Those who have gone forth may not be given as slaves to others. They may not be suppressed [by tax]. Having placed them on the protection of householders, they are not subject to lawsuits." ${ }^{14}$

The Changbu (lCang bu) Inscription, issued by Tridè Songtsen's son, Tritsuk Detsen, from the ninth century, chronicles the foundation of the Changbu Temple and displays similar sentiments. The edict states that the gifts given in perpetuity should not be lost and that the great temple and its subjects cannot be taxed or punished. ${ }^{15}$ This edict places the judicial authority, over both the Sangha and the laity, firmly in the hands of the monks residing there.

An early law code ascribed to Trisong Detsen, despite having been only poorly preserved in secondary sources, makes a distinction between monks and lay tantric practitioners. It stipulates that people are to venerate and bow to monks and suggests harsh punishments for those who insult or harm them. ${ }^{16}$ While they clearly enjoyed a privileged position, monks were not above the law. In fact, legal regulations from Imperial times, as preserved in later historiographical records, show that punishments of crimes against the king were harsher than those committed against the Triratna, which of course included the monkhood. ${ }^{17}$ By contrast, "The History of Ngari" ${ }^{18}$ states that in 988, then-ruler of Western Tibet Lha Lama Yeshé Ö (lHa bla ma ye shes 'od) issued a "religious edict"19 that prioritized religion over the "secular." The text reports that his whole entourage swore an oath to uphold this, calling upon the protector Pehar as a witness. ${ }^{20}$ The (legal) authority of the ruler with regard to the monasteries seems to have been greater in earlier times than later on. ${ }^{21}$

It appears that the privileged legal status of Tibetan monks established early on set the stage for centuries to come. Monasteries, together with their estates, seem to have been "judicial islands": the monastic authorities had the power to try and 
punish whomever was seen to be in the wrong, be they monks or laypeople. Dargyay reports that, in the first half of the twentieth century, monastic estates even had two levels of (monastic) judicial authority: The lowest judicial court was headed by the steward of the monastery, the higher one by the manager. ${ }^{22}$

At the same time, monks were supposed to follow the secular state laws as well as regional laws, which were often not more than customs. Many of these customs were already included in the vows and rules to which monks were committed in the first place, such as not to kill and not to steal. The most basic and widespread "secular" legal code is "The Sixteen Pronouncements." ${ }^{23}$ A number of variations and adaptations exist, resulting in various numbers of pronouncements, but the text is traditionally attributed to Songtsen Gampo. The colophon of one relatively early variation, “The Thirteen Pronouncements," ${ }^{24}$ mentions king Ādarśamukha ${ }^{25}$ as the one making the pronouncements. This person features in the Jàtakas as a previous birth of the Buddha, who was known as a just king. ${ }^{26}$ The ascription to him thus maintains the secular nature of the code while granting it the authority of the Buddha. This textual genre had a mainly symbolic function, but nonetheless was deeply ingrained in the "legal consciousness" of the Tibetans. ${ }^{27}$

Connected to these pronouncements are the sixteen human rules or norms often attributed to Songtsen Gampo. ${ }^{28}$ A relatively late set of monastic guidelines for Ochu Gon from 1918 connects these sixteen rules to upholding monastic discipline and basic ethical behavior: "Because the purity of the Sangha's discipline, the foundation for the well-being of the region, and the practice of the ten virtues is dependent of the sixteen pure 'human rules,' monks and laypeople all need to be mindful and conscientious of not engaging in actions that go against these." ${ }^{29}$ Equally, the guidelines for Mindröl Ling note that monks had to adjust their behavior according to the contemporary and contextual "human rules." ${ }^{30}$

When monks committed particularly heinous crimes, such as murder and treason, they tended to be tried under state law. ${ }^{31}$ Bell writes that a monk who committed a murder would first be flogged and expelled from the monastery and then handed over to the secular authorities. ${ }^{32}$ A similar type of legal ideology is attributed to Emperor Xuanwu (宣武 r. 500-516), who attempted to regulate the Chinese Sangha in an edict:

Since black and white [monk and lay] are two different things, the laws (法 fa) and Vinaya (律 $l u$ ) are also different. ... From this moment on, let all Buddhist monks who commit the crime of murder or worse be judged in accordance with secular laws. For all other crimes, let them be judged according to the Vinaya. ${ }^{33}$

While in Tibetan society there occasionally was a rather strict theoretical divide between state and religious justice, in practice, the two were often intertwined. This, of course is also related to the fact that politics and religion were combined, ${ }^{34}$ the most notable expression of this being the office of the Dalai Lama. Bell mentions that the Thirteenth Dalai Lama would occasionally try legal cases when he 
was a novice (probably śrammanera) but that he stopped this practice later on, ${ }^{35}$ likely when-or because-he became a bhikșu. Within existing Buddhist ideologies, there are many justifications for why a ruler should bring a wrongdoer to justice. ${ }^{36}$ In the monastic guidelines, the implementation of rules is often portrayed as being crucial to the (social) order. This sentiment is found in the set of monastic guidelines for Sera monastery from 1820: "For the teachers and the disciplinarians and the like not to implement the rules is to undo the Teachings from their base." ${ }^{37}$

\section{GOLDEN YOKES: RELIGIOUS LAWS AND \\ SECULAR LAWS}

The secular and religious "law systems" are regularly described as "the golden yoke" and "the silken knot" respectively. In post-Imperial sources the terms were used to describe the government of Trisong Detsen and Tritsuk Detsen. Nyangrel Nyima Özer (1124-1192), in his description of the era of fragmentation,,$^{38}$ notes that during this time "the silken knot of the rule of the Dharma unraveled and the golden yoke of the rule of the king broke." ${ }^{39}$ The most common descriptions attached to this imagery convey that the golden yoke of secular law is heavy and that the silken knot of the religious law is tight, ${ }^{40}$ implying that both are tied around and resting upon the necks of citizens.

Interestingly, at least two sets of monastic guidelines have "golden yoke" ${ }^{41}$ in their title. The set of guidelines written by the Seventh Dalai Lama for Namgyel is called “The Golden Yoke: The Monastic Guidelines Written for Namgyel Monastery" ${ }^{2}$ The chayik for Tashi Lhunpo from 1876 also carries this phrase in its title and "explains" it in verse:

This magnificent golden vajra-yoke

That evokes joy among many intelligent ones,

Clamps down on foolish people who behave badly,

While it strengthens the two good traditions ${ }^{43}$ and spreads joy. ${ }^{44}$

Here the phrase "golden vajra-yoke" appears to suggest that both the Dharma and secular authority were represented by this text, and indeed by its author, the Eighth Panchen Lama, whose political position had to be asserted and reasserted so as to prevent the Lhasa government from overpowering the monastery and its significant domains and assets. ${ }^{45}$ In other cases, however, the golden yoke only refers to the internal rules of the Sangha, such as in a chayik written by the Thirteenth Dalai Lama in 1927: "The internal rules of the Sangha, which are in accord with place and time and which are in fact an abbreviated form of skillful means, are clean like the stem of a lotus and suitable to carry ${ }^{46}$ like a golden yoke." ${ }^{47}$

For the Fifth Dalai Lama, the golden yoke belongs to religious imagery, although this does not necessarily exclude a possible secular affiliation. The closing verses 
of his monastic guidelines for Drepung convey that he sees the combination of the two traditions as leading to the happiness of all, with the Dharma being the primary factor:

By means of the extremely heavy golden yoke

Of the Buddhist law [upheld] at the palace that possesses the two traditions

That rules every single beautiful region of the golden ones,

May beings be led toward glorious happiness. ${ }^{48}$

The combination of secular and religious traditions was seen by many as the ideal way to rule a country. The legal code for Bhutan from the eighteenth century expresses a similar view, while using different imagery: "By placing the bejeweled parasol of the Buddha's Teachings on the spokes of the wheel of the state law, the field of merit will remain for long." ${ }^{49}$

The picture that emerges from the above examples portrays the need to uphold the law-be it religious or secular-for the sake of the general well-being, in which social order could be said to be implied. This suggests that both types of law implemented punishments for similar reasons and in similar ways..$^{50}$ As previously alluded to, this implementation of the rules, as contained in the monastic guidelines, concerned both monks and laypeople. We now turn to the way, and the extent to which, monasteries were involved in laypeople's justice.

\section{JUSTICE, THE MONKS, AND THE LAITY}

A number of monastic guidelines make it clear that the extent of jurisdiction was not necessarily based on the division between laypeople and monks, but rather that it was geographically determined. The moment one found oneself on monastic territory, one needed to abide by the rules belonging to that institution. This is in fact a more general Tibetan notion, as captured in an oft-used proverb: "One should abide by the laws of the land of which one drinks the water." ${ }^{1}$

The Tibetan secular laws appear to have been viewed as "reliable suggestions" 52 rather than records of case law, and it is likely that this was also true with regard to local laws and customs. Many, presumably, were passed on orally. This was in most cases also true for monastery-level jurisdiction: most of the laws or rules would have been understood by the local populations, but were not accessible to them. The monastic guidelines then only address those instances in which the rules were regularly broken, when the rules were seen to be in need of clarification, or when they concerned activities that the monk authors felt particularly strongly about. One example is the killing of animals - either by hunting or slaughter-on monastic territory or within view of the monastic grounds.

The connection between territorial control-in particular with regard to hunting - and the monastic guidelines has been noted by Huber. He discusses the 
"sealing" ${ }^{33}$ of specific areas, which "applied to a generally smaller, well defined unit of territory over which the monastery had rights and control." ${ }^{54}$ The descriptions of monastic territory given in the guidelines are sometimes very detailed, while others are vague. The guidelines for Sera Je note that in the areas east of Sera: "One is not to buy or sell alcohol or slaughter animals. One may not burn black things, ${ }^{55}$ or keep pigs and chickens. One is not to hunt birds and wildlife in the mountains behind the monastery and in the vicinity." ${ }^{56}$

The monastic guidelines for Pabongka are rather detailed with respect to the area where hunting was not allowed, which then could indicate the boundaries of monastic jurisdiction. ${ }^{57}$ Kongtö Dungkar monastery in upper Kongpo forbade hunting and fishing in the hills and valleys up to one $k r o s a^{58}$ from the monastery. If these types of activities did take place the area had to be "sealed." ${ }_{59}$ While this "territorial seal," according to Huber, became a "legislative act," ${ }^{\circ 0}$ it is not known here how exactly this legislation was enforced. In other monastic guidelines, various punishments for killing animals within monastic territory are suggested. Perhaps the most common punishment was "the offering" of a communal tea-round. The monastic guidelines from 1903 for Pelkor Chödè in Gyantse set out this punishment of offering a tea-round when a hunter or trader is found to have killed an animal within the stipulated parameters. ${ }^{61}$

Huber notes a more intriguing punishment, given by the Thirteenth Dalai Lama concerning Rongpo Rabten monastery: "When itinerant game hunters appear, they should be punished by gathering their weapons in the protector's [sic] temple and in addition exhorted once again to observe lawfulness." ${ }^{2}$ According to Huber, other monastic guidelines mention that hunters and the like should be made to recite religious texts in the protectors' chapel. ${ }^{63}$ Oaths even today are regularly sworn by the laity in the presence of the protectors. The chapels tend to be laden with (ancient or now defunct) weaponry, possibly in part for the above reasons. According to the traditional narrative, the protectors at the monastic territory were often the original chthonic inhabitants of the area, who were "converted" to Buddhism - thus to harm their land, and everything on it, would equate to upsetting these spirits.

Punishing laypeople for killing animals within the vicinity of the monastic territory was not simply seen as a prerogative of the monasteries, but as their duty. Monks, the guidelines tell us, were even burdened with the responsibility of patrolling the area and catching the lawbreakers. In the case of Phulung monastery ${ }^{64}$ in 1947, it even came with extra paperwork:

When illegal activities are committed by a couple of evil people, the lamas and the monks all need to-by means of starting a vigorous investigation-create a written agreement, in which a promise is made not to reoffend, or else there will be a set punishment, such as three bricks of tea, soup, flags, communal tea-rounds, scarves, and the like. ${ }^{65}$ 
Monastic grounds-often not agricultural land, and thus without much economic value-were to be protected by the monks. The guidelines for Tashi Lhunpo even note that monastic officials had to guard against animals moving about in the hills nearby, because their presence or their overgrazing could cause landslides, from which the monastery had to be protected. ${ }^{66}$

For the monks of Reting, however, the reasons for protecting the area around the monastery were formulated differently: "The birds and wild animals in this forest of Reting, the essence of enlightenment, and the foundation for the Kadam, are said to be the emanations of bodhisattvas. Therefore, no one-be they Mongolian, Tibetan, Hor, or nomads - may do them any harm, steal or kill them." ${ }^{6}$

Sometimes, the time spent protecting the monastic lands had some perks, either for the monastery as a whole or for the individual monks. The monastic guidelines for Pelyul Darthang describe the boundaries of the monastery and then state:

From where one can see the monastery, inside or outside, there abattoirs may not be maintained. If slaughter takes place, there is the punishment of the price attached to the meat. And if the buyers are still there then the meat and the price paid for the meat need to be both taken away. ${ }^{68}$

This means that both the seller and the buyer of the meat would be punished for being complicit in the maintenance of an illegal slaughterhouse. At the same time, of course, both the meat and the money could be confiscated, which may have served as an incentive for the monks to patrol the area. This early twentiethcentury chayik also suggests a similar type of punishment for the selling of alcohol on monastic grounds: "When people buying and selling alcohol find themselves on monastic grounds, the alcohol and the profit of the alcohol need to be taken away." ${ }^{9}$

In other sets of guidelines it is more common to punish those carrying alcohol to the monastery by actually destroying their wares. The Mindröl Ling chayik states: "Even when a layman simply carries a vessel of alcohol beyond the bordermarker, he needs to be punished, for example by breaking the vessel." ${ }^{70}$ In Tsurpu the situation was similar, but the difference was that there actually needed to be an intention to break the rules: "When local people, pretending to be newly arrived visitors, turn out to be carrying vessels of alcohol back and forth to the residencies within the monastic compound, then the guards of the residencies have to take the discovered alcohol vessels and destroy them without trace." ${ }^{71}$ Interesting here is also the mention of guards, who were likely to have been charged with "policing" the monastic compound.

The destruction of wares may have been the lightest of punishments, as a government decree from 1882 specifically intended to tackle the "use" of alcohol and women. ${ }^{72}$ This decree, written for all the major Geluk monasteries in the Lhasa area, ${ }^{73}$ states: "It is customary that when laymen or alcohol sellers are in any way 
seen, heard, or suspected of offering ${ }^{74}$ alcohol to monks, a punishment according to secular law, which is heavy as a mountain, is given, so as to set an example." 75 In other cases, it was the trespassing itself that had to be punished. Women caught fetching water within the monastic compound had to be given a suitable punishment, such as being required to offer a butterlamp. ${ }^{76}$

It appears that monasteries, when it concerned the wider territory for which they were responsible, exercised their judicial authority regarding laypeople only in the most serious cases (such as killing), but when laws were broken "closer to home" the rules became stricter. It could be said that the laity and monks had to heed the same authority as soon as they found themselves within the gates of the monastery itself. A work on Tsurpu monastery remarks the following: "Once within the gates of the monastery, whether one is lay or ordained, high or low, male or female, young or old, everybody needs to heed the instructions of the three, the disciplinarian, the master and his aides, which is in accord with the contents of the Garchen's monastic guidelines." 77

In the monastic guidelines for Drepung from 1682, the ordinary laypeople and monks also had to comply with the same basic rules: "Ordinary laypeople and monks may not ride their horses within the monastery. Loud songs and shouting at each other from afar and any loud noises may not be uttered." ${ }^{8}$ In Jampa Ling too, the laity was expected to behave more like monks when visiting the monastic compound: "Within the boundaries of the monastery, it is inappropriate even for laypeople to fight, to sing, to smoke, to use snuff, or to play mahjong, and so on. Therefore, those who knowingly make such mistakes should be punished appropriately."79 Similar kinds of typical lay behavior were also forbidden when people visited the monastery of Tengpoche in Nepal, and it was the disciplinarian who was given the task of making sure that these rules were upheld, so that "outside guests do not do things that are forbidden such as drinking alcohol, fighting, being loud and laughing." ${ }^{80}$

Justifications why laypeople were not allowed to behave in a certain way tend not to be given in the sources at hand. The guidelines from 1913 for Thobgyel Rabgyé Ling by the Thirteenth Dalai Lama lists things that neither the laity nor monks could do in the vicinity of the monastery, such as riding horses, singing, and having hairstyles that incorporate fabric, as these "are things that are disrespectful to the Sangha." ${ }^{81}$

The above selection of examples that show laity being affected by the monastery's rules strongly suggests that many Tibetan monastic institutions-at least from the seventeenth century onward and likely before that as well-held judicial authority over their own territories and were able to punish laypeople for killing animals, trespassing, and treating the monastic grounds as their playground. ${ }^{82}$ Not only did rules pertaining to the laity exist, they also appear to have been exercised. The chayik are the documents par excellence that indicate these local laws 
and to whom they pertained. In the context of Tsurpu, this level of jurisdiction is explained succinctly:

In short, all the monks, high or low, who are part of this monastery, as well as the faithful sponsors who live in the mountains surrounding the monastery, as well as the pilgrims-basically all, monks or lay, man or woman, good or bad-need to take into account the contents of the precious chayik that establishes the law of the disciplinarian, the masters, and their assistants. ${ }^{83}$

\section{MEDIATION, DisPUTES, AND COMMUNAL VIOLENCE}

Able monks were often employed as intermediaries, often on a voluntary and individual basis. In particular, highly regarded monks were seen as ideal candidates for the job of "go-between" or mediator. ${ }^{84}$ Tibetan historiographical accounts abound with narratives of revered monks preventing battles and other conflicts. ${ }^{85}$ In many Buddhist cultures, the "holy man" is often seen to mediate between various social groups. ${ }^{86}$ The Vinaya limits the extent of this mediation: the monk is not to act as a matchmaker, nor is he to engage in marriage counseling. For Tibetan monks, mediation of legal or violent disputes was not out of bounds. In Labrang, it seems, people even "preferred adjudication by the monastery" ${ }^{87}$

According to Goldstein, in Central Tibet this type of adjudication was the first resort for civil disputes, and it was only when such adjudication failed that cases were brought to the local leader. ${ }^{88}$ This was also the case in other Tibetan Buddhist areas. In Spiti in the nineteenth century, people rarely had "recourse to the law courts, or even to the primitive justice dispensed by their chief the Nono." When someone's word was not trusted, he was made to swear an oath. ${ }^{89}$

Trusted and unbiased men were thus often called upon to intervene in disputes. In areas where monastics had good relations with the local population, these men were often monks. Of course, mediation and adjudication took place both inside and outside the monastery's walls. In some cases, monks are even reported to have pleaded on behalf of certain criminals for a reduction of a punishment that involved mutilation..$^{\circ}$ When monastic guidelines report on monks acting as conciliators, it is often not specified who their "clients" are. The Mindröl Ling guidelines mention that this role was to be taken seriously: "People who are strong in giving council should communicate sincerely and decide matters in accordance with the truth."91

For internal monastic matters, the obvious candidate for mediation would be the disciplinarian. The guidelines for Pelyul Darthang indicate that this person was not handed an easy task:

From now on, the disciplinarian should not, when quarrels and suchlike occur, oversee major or minor disputes-whether internal or external, general or specific, large 
or small-that are not relevant. Surely, one needs to continue to treat all the external and internal rules of the Teachings with priority. Therefore, no one should encourage him to act as go-between for others in disputes, whether they be high or low. ${ }^{92}$

From the above can be gleaned that the disciplinarian was asked to adjudicate various, perhaps personal, disputes, but that was not part of his job description. The involvement of the disciplinarian could easily lead to him losing the impartiality that was emphasized by so many chayik.

Disputes-the guidelines demonstrate-seem to have been a common feature of monastic life in pre-modern Tibetan societies. Occasionally, these arguments became violent. Precautionary measures had to be taken, such as the ban against any type of weaponry being brought into the monastery. The rules regarding this issue for Pelyul Darthang monastery are like those of many other monasteries: "It is not allowed for anyone to ride a horse, wear a knife, carry guns and the like within the monastic grounds." ${ }^{93}$ For this monastery, it cannot have been very unusual for monks to carry arms and to use them, for it is stated: "Only those monks who have never used knives and guns may assemble during poṣadha ${ }^{94}$ and the summer retreat." 95

A Ladakhi monk who lived in Yangri Gar in Central Tibet before 1959 was able to confirm that monastic fighting was a rather ordinary occurrence: "In Tibet there were punishments for fighting, and there was a fair amount of fighting going on, but not here in Phiyang. If you would fight here, you would get expelled." 96 The most dangerous types of disputes were seen as those involving various groups of monks, pitted against each other, as it could lead to communal violence. One of these clashes is actually mentioned in the Drepung monastic guidelines. Apparently a Mongolian had fired a gun, thereby killing a monk who-to judge from his name-must have been a scholar monk. This episode seems to have occurred in the context of intercollegial feuding, for the text states:

Even though previously, when the monastic houses fought over people and possessions, arrows and catapults used to be employed, other than the Mongolian Ngödrup Gyatso (dNgos grub rgya mtsho) firing a gun and killing Lubum Jampa (Glu 'bum rab 'byams pa), nothing else has occurred. Still, from now on firearms should not be used. ${ }^{97}$

The author goes on to warn that, in the case of illegal actions such as causing a rift in the Sangha and bringing down the Teachings by, for example, colleges and houses fighting each other, the ringleaders together with their gang were to be punished according to state law. ${ }^{98}$

It was worse when conflicts were not confined to the monastery, but when a third party was invited to participate. The same author of the Drepung monastic guidelines, the Fifth Dalai Lama, also wrote the guidelines for Gongra Ngesang Dorje Ling in 1664. His remarks highlight the volatile situation in which this 
recently "converted" monastery found itself. He saw it as a breeding ground for communal violence:

When one has solicited the help of one's close friends or country-mates, who come into the compound as an army and act as accomplices and aides, joining in as avengers, and when the lama, the chant master, and the disciplinarian behave very badly by not considering it important to impose order, then the original ringleader needs to be expelled. ${ }^{99}$

Interestingly, monastics these days are still seen to take the side of their fellow countrymen when arguments arise, which is due to misplaced loyalty causing them to "throw their weight behind someone in a dispute just because he is from their locality, disregarding the right or wrong of the situation."100

This strong sense of local loyalty was compounded by the fact that monastic houses were, and still are, usually organized on the basis of regional origins. For monks who were a regional minority, this could result in getting bullied, as the chayik for Pelyul Darthang suggests: "No monk of this monastery, whether big or small, high or low, is to disturb the monks who have come from elsewhere by teasing, calling them names, or insulting them." ${ }^{101}$ In this regard, the guidelines for Mindröl Ling warn: "Do not start fights that divide the community by slander, out of bias for one's own house."102

The Seventh Dalai Lama, as usual very much in agreement with the Fifth, notes in his guidelines for Namgyel Dratsang the following on communal fighting:

Fights between colleges, regional groups, older and newer [monks], or mass fights with monks are all against the law and constitute "causing a rift in the Sangha"103 and "bringing down the Teachings." 104 As the ringleader with his gang is punishable under the secular law, there is no need to go into detail here. ${ }^{105}$

Thus, monastic infighting was deemed to be a crime that was to be tried according to secular law, while this also was judged to cause a rift in the Sangha and to bring down the Teachings. This is a clear indication of the interwovenness of religious and secular policies and ideologies.

\section{INTERNAL JUSTICE: CRIME AND PUNISHMENT}

Throughout this book we find references to different types of punishment for various monastic misbehavior. The most common one is the "offering" of something. This can be offering prostrations, butter, scarves, or money. Other punishments are doing menial tasks, getting expelled, or getting expelled as well as tried according to secular law. ${ }^{106}$ More sporadic are mentions of corporal punishments. ${ }^{107}$ It is important to note that the severity of penances varies greatly among the monastic guidelines, and there is thus no overarching understanding of what punishments fit which crimes. Furthermore, the manner in which monks are punished is often left to the 
discretion of the monk officials (usually the disciplinarian). In some cases, however, the penalties given are rather detailed. The chayik for Drigung Til from 1802 has a long section on crimes and punishments. It first addresses communal violence:

Because this monastery consists of a large area, it would be wholly inappropriate to hold biases toward the upper or the lower part: all need to uphold the same ideals. If there are any quarrels, arguments, or physical fights, then [the punishment is] a communal tea-round, a hundred prostrations, three sets for the lama, ${ }^{108}$ and a ceremonial scarf for the manager and the disciplinarian. If implements are used such as stones, sticks, or claws, ${ }^{109}$ then [the punishment is] a communal tea-round, three hundred prostrations, pole-flags and scarves, five sets for the lama, and three sets each for the manager and the disciplinarian. If knives are drawn and blood is shed, then [the punishment is] a communal tea-round, a thousand prostrations, pole-flags and scarves, seven sets for the lama, and five sets each for the manager and the disciplinarian. ${ }^{110}$

Here we see a gradual increase in the severity of the punishment, as the harm inflicted on others gets more serious. The punishment is about three times more severe when one inflicts harm with a knife instead of through one's hands or words. The text continues:

When people drink alcohol or smoke tobacco, then, because it smells bad and falls under intoxicants, or when someone arrives beyond the black pile of stones ${ }^{111}$ riding a horse, [the punishment is] a communal tea-round, three thousand prostrations, pole-flags and scarves, nine sets for the lama, and seven sets each for the manager and the disciplinarian. ${ }^{12}$

This means that drinking, smoking, and riding horses into the compound are punished more heavily than stabbing a person with a knife! There may be a number of explanations for this, but it is likely that, while the previous penalties in all likelihood involved only monks, the latter penalty also affected laypeople. Perhaps the general consensus was that they could be fined more heavily than monks. The text goes on to describe "crimes" that could only be committed by monastics:

If something illegal happens that is an obvious defeat (pham pa, S. pārājika) such as sexual conduct (S. abrahmacārya), then [the punishment is] a communal tea-round, ten thousand prostrations, pole-flags and scarves, ten sets for the lama, and nine sets each for the manager and the disciplinarian. Having offered this, then if he stays in the monastery, he needs to [first] give back the remainder of his vows ${ }^{113}$ and if he does not genuinely abide by the trainings he then has retaken, he will be expelled. ${ }^{114}$

It seems here that, contrary to what is often thought, sexual conduct did not necessitate the expulsion of a monk. ${ }^{115}$ Rather, the text explains what "reparations" needed to be made, which included the retaking of the monk's vows.

The text concludes its section on punishments: "If one talks back to the lama, or if one physically retaliates against the manager and the disciplinarian, all this 
person's things need to be neatly collected and he then is expelled." ${ }^{116}$ The suggestion here is that answering back to the lama or punching a disciplinarian was potentially punished more heavily than breaking one's root vows, for here the option of staying in the monastery is not given. Possibly, this type of rebellious behavior was seen as more heinous than sex-the most un-monk-like behavior of all. However, in Mindröl Ling in the late seventeenth century, talking back to the disciplinarian was punished according to the severity of the occasion: "When there is backtalk the punishment is [the offering of] butterlamps. . . If there is physical resistance he is either expelled from the monastery or made to give a communal tea-round, scarves or butterlamps of one measure depending on the gravity of the offense." ${ }^{117}$

In Phulung monastery in 1947, merely verbally retaliating or resisting the disciplinarian was punished relatively lightly: "When someone, while having done all sorts of things, still utters talk such as 'I am important, I am powerful' and-out of disregard for the disciplinarian-talks back to him, [that individual] needs be punished by doing prostrations, ranging from fifteen hundred through twenty-five hundred, depending on the gravity of the offense." ${ }^{118}$

When punishment is mentioned in the monastic guidelines, the flexibility of the rules is often emphasized and, in most cases, the type of punishment is left to the local monastic officials. In Pabongka monastery too, when actions not in accordance with the Vinaya were committed, the severity of the punishment had to fit the misdeeds: this could be the offering of butterlamps, scarves, or a communal tea-round. ${ }^{119}$ By contrast, in Thailand in the 1960 s, offenses incurred by the monks were punished by making them do domestic chores, such as sweeping the compound or cleaning the latrines. ${ }^{120}$

More in line with the Tibetan way of punishment, in early twentieth-century China, punishments were often physical, but fines of two to ten Chinese dollars were also common. If the offender did not have the money he would be beaten. Expulsion was rare and could only be demanded by the abbot. In the Chinese monasteries where the emphasis on meditation was less strong, penalties were milder. To judge from anecdotal information, at Tibetan monasteries the opposite seems to have been the case. In China, the offending monks were sometimes made to do three prostrations in front of a Buddha image. Monks with no money to pay the fine would have to do a greater number of prostrations. The mildest type of penalty was chanting a sūtra, ${ }^{121}$ something I have not come across in the Tibetan context.

While in the Chinese monasteries the emphasis was on monetary punishments, this was relatively unknown in Tibet, partially also due to the relative scarcity of cash money. However, in recent times, it is more and more common for monks to be fined. In 200o, Sera Me monks in India were fined twenty-five rupees every time they skipped a debate session. ${ }^{122}$ In the scholastic college of Drigung 
monastery in India, getting involved in a fight cost three hundred rupees. ${ }^{123}$ It is unclear what the "proceeds" of these fines were intended to be spent on.

\section{A NOTE ON FORCED “OFFERINGS”}

All in all, the above-mentioned penalties are relatively light and-at first glanceappear to be allowing a wrongdoer to "pay" for his bad actions by giving him a chance to accumulate merit, perhaps similar to doing penance. The prostrations, also the punishments of choice in sixth-century Chinese Chan monasteries, ${ }^{124}$ suggest that this was an opportunity for the individual to generate good karma (although it is never reasoned in this way). Additionally, as these prostrations appear to have most frequently occurred in the presence of all the other monks, this punishment could also have been used as a way to put a rebellious monk in his place. ${ }^{125}$ It has been noted that "[f]ines in kind were common, but they were always described as 'offerings'." ${ }^{126}$ Furthermore, the texts conceptualize punishment very much as punishment (and not necessarily as offerings), since the word "punishment" (chad pa) is also employed, often in the same line. Still, butterlamps, scarves, and prostrations are first and foremost thought of as offerings.

The counterintuitive status of these punishments is also remarked upon by Ngawang Peljin:

The internal rules talk about how first to tell someone he made a mistake, and that when it happens again he needs to do a hundred prostrations or give a hundred butterlamp offerings with his own money. Normally, butterlamps are offered out of faith, but here the person has to offer, whether he has faith or not. ${ }^{127}$

The offerings then, while by no means voluntary, were a way to practice generosityalthough it can be debated how much merit would be accrued if the giver gave against his will. An important feature of the prostrations is that they were often done during the assembly: all of the monks present would then know that the monk did something wrong. It can also be seen as a way of making amends with a community whose reputation the misbehaving monk had potentially damaged.

The forced offerings that the authors of the monastic guidelines recommend to give as punishments are not primarily focused on the individual's morality or karmic status. However, there may have been an element of these punishments restoring a balance, within the community but also among the deities to whom the offerings were given.

\section{ON PHYSICAL PUNISHMENT}

Monastic punishments were not in all instances easily rationalized from a Buddhist viewpoint. Corporal punishment, according to many eyewitness accounts in Tibetan monasteries, is one such example. The information on physical punishment 
in Buddhist cultures is diverse. For some, the case is quite clear-cut: "First of all we must note that there was no corporal punishment in monastic Buddhism." ${ }^{128}$ Pachow, in a similar vein, comments that the Buddhists "do not inflict upon anybody any corporal punishment nor impose any fine, their punishments are comparatively very light." ${ }^{129}$ More nuanced is the observation by Gethin, namely that "the use of physical violence as a punishment for breaking the rules of the monastic code seems nowhere to be endorsed in the early Buddhist vision of monastic life." ${ }^{130}$

While indeed in the Vinaya materials there are no known references to structural physical punishments for monks breaking rules or vows, textual material and oral history from a wide range of Buddhist cultures from different eras suggest that - as was (and is) the case in the domestic sphere-these punishments were not unheard of in monasteries. The British explorer Pereira, who visited Labrang monastery in Amdo in the early twentieth century, describes in some detail the monastic punishments he was told about:

For discipline, there is a president (Jewa). ${ }^{131} \mathrm{He}$ has powers of punishment. For grave offenses a sheet of paper is put over the monk's face and he is branded on the forehead with a red-hot key and is then led to a small door and banished from the monastery. Another punishment is cutting off the ears and nose, but this is rarely, if ever, practiced. Another punishment is to suspend a monk by the hands from a tree, either entirely or with his toes just touching the ground, and he is kept suspended for different lengths of time up to two or three days. The commoner punishments are beatings, or else being fined. Even lamas are liable to be punished in these ways, though generally they are given the opportunity of getting away. ${ }^{132}$

Another traveler account is by Schram, who visited the border areas of Amdo and China in the 1920s: "At night, the disciplinarian with some of his lictors, armed with rawhide whips, makes a tour of the lamasery. Lamas found brawling, quarreling, or fighting are brought to the court of the intendant, where penalties are meted out in various brutal forms."133

While earlier authors, with their orientalist tendencies, may have been keen to point out the "brutal" punishments Tibetan monks bestowed upon each other, the most common reports are of physical punishments that were not excessive but also no mere slap on the wrist. Rogue monks tended to get punished by having to do prostrations or by getting beaten - neither for a prolonged time nor severely-by switches on the backside. ${ }^{134}$ In Tibet, according to one of my informants, often only the young monks would receive these types of punishments; it was not considered an appropriate punishment for monks who were more mature. ${ }^{135}$ Lobzang Döndrup, an elderly monk from Ladakh who spent a number of years in Drepung in Tibet in the 1940s and '50s, recounted how discipline was maintained there:

If you would do something against the rules, the house-teacher would beat you with a stick. ${ }^{136}$ There were several people who would keep order in the monastery: the disciplinarian, the abbot, the disciplinarian's assistants: if you would do something bad 
they would report you to your house-teacher. He would then beat you or give you some kind of punishment. Prostrations were also a punishment, but it was mostly the stick. We never had to pay monetary fines or anything like that. ${ }^{137}$

In some monasteries, fines rather than offerings were an accepted way to penalize a monk. The chayik for the Nyingma monastery Tengpoche in Nepal from 1918 states: "When a small number of evil people are involved in improper things that are a disgrace to the Teachings, disregarding what is right, then by means of investigation, strict punishments that befit the wrongdoings need to be imposed, which may be either physical or material." ${ }^{138}$ In some cases, the type of corporal punishment is specified, such as in the guidelines written by the Thirteenth Dalai Lama in 1927 for a Central Asian monastery: "Arguments and fights should be definitely punished relative to the wrongdoings, setting an example. This ranges from offering butterlamps and scarves to the protectors, to doing either a hundred or a thousand prostrations, or even to getting whipped." 139

According to one informant, elderly monks could often be overheard exchanging "war stories" of their youths spent in the monasteries in pre-1950s Tibet, saying, "I did this and this, for which I got thirty lashes with the whip." ${ }^{140}$ Currently, in Tibetan monasteries beating is no longer an acceptable form of discipline: these practices are being gradually phased out. ${ }^{141}$ Some monk administrators, however, talk about how the old ways were more effective. Lama Tsültrim, a monk high up in the administration of a large monastery in exile, is highly critical of current-day discipline:

The monks these days go everywhere. In the old days you needed to ask the disciplinarian for permission before you could go outside of the monastery. If you would get caught you would get fifty strikes on the backside. Now there is no physical punishment any more. Now the monks are all over the settlement and wander about at night. $^{142}$

There are some monastic guidelines that seem to suggest that laypeople too were liable to get punished physically. The guidelines for Tashi Lhunpo, for example, outline the rules with regard to the use of alcohol. This eighteenth-century text states that no one, not even the lay officials, could drink or even carry alcohol in Tashi Lhunpo, and that people caught buying or selling intoxicants would receive a suitable corporal punishment to make them see the error of their ways, and that they would not be allowed the option of a payoff. ${ }^{143}$ A later set of monastic guidelines by the Thirteenth Dalai Lama for a monastery in Chamdo ${ }^{144}$ from the 1920 also suggests physically punishing anyone who broke the rules, be they lay or monastic: "In accord with various relevant legal decrees, which resulted in hunting being illegal in the [previously] established areas, such as behind and in front of the main monastery and its branches, when people do not uphold this, they need to be physically punished." 145 
Corporal punishment is mentioned only infrequently in the monastic guidelines. It is important to bear in mind that the Tibetan chayik, as other Buddhist monastic guidelines, often merely portray a normative picture: the way procedural justice was imagined by the authors. Oral accounts and the like then show us to what extent these rules were put into practice and whether the general monastic attitude to justice concurred with that found in written sources. With the information at hand, it is difficult to ascertain the degree and manner of physical punishment that took place in the monasteries. A set of monastic guidelines for the Sakya Mangtro (Mang spro) monastery in Ladakh, written by the King Nyima Namgyel (Nyi ma rnam rgyal) in 1711, threatens with physical and even capital punishment, but only as an instrument of state law:

As it would not be right to become worse than householders, by taking into consideration the honor of the Teachings and the beings based on the religious rules and the state law, a lama should not diverge from this path. A doer of great misdeeds is confined to his monk quarters ${ }^{146}$ and all that he has is confiscated by the monastic authorities. After careful investigation, he is expelled by the gandi being beaten, ${ }^{147}$ thereby preventing any reoccurrence among the pure ones. Afterwards, one is not to aid him. After this, no one, be they high or low, monk or lay, in whatever capacity, is allowed to act as his support or his accomplice. People who innocently disregard this will be penalized heavily by means of punishments of body and life through the secular law. Therefore, it is important for everyone to be very clear about what is right and wrong. ${ }^{148}$

Within the Tibetan secular courts, physical punishments and even the maiming of convicted criminals were not uncommon practices. These types of punishments did pose a challenge to monastics involved in legal issues. French's monk informant who used to work at the courthouse in Lhasa stresses that he "as a monk" was not allowed to have anything to do with such punishments. ${ }^{149}$ By contrast, the people who punished the monks in the monasteries must have always been monastics themselves.

\section{THE PUNISHMENT OF EXPULSION: PĀRAJIKA AND \\ OTHER REASONS}

Among the lists of punishments that feature in most chayik, expulsion ${ }^{150}$ is often given as the last resort, the highest possible penalty. But what crimes deserved such punishment, and what did it actually mean to get expelled? The threat of expulsion has been alluded to in previous chapters. According to information based on oral history, actual expulsion was rather rare. In most, but not all, cases, people were expelled when one of the four "root vows" was broken. The procedures of expulsion, as described in the monastic guidelines, are rather intricate. The 1947 guidelines for Phulung elaborate on the process: 
When it turns out that someone has gone against [any of] the four root vows, he will definitely be expelled from the Sangha. He-whoever it is-should offer a hundred prostrations in the back row during assembly. After that, he kneels and the disciplinarian sternly relates his misdeeds in public. Then, his monastic robes are taken away from him. He is made to wear white clothes ${ }^{151}$ and he is justly given two hundred lashes of the whip in order to make him an example for everyone to see. After that, as settled on paper and established in the sūtras, he is expelled. ${ }^{152}$

The Thirteenth Dalai Lama suggests a slightly milder approach and recommends a fine for transgressing monks in Jampa Ling in Chamdo: "Those who have incurred defeats need to first give scarves to the people of their own college and then they give a fine of twenty-five official silver coins. ${ }^{153}$ After that, as settled on paper and established in the sūtras, they are turned out."154 A similar type of rigorous approach was suggested by the monastic guidelines for Menri monastery. Cech translates: "If the four root vows are weakened, then there should be no delay in expelling the monk from the monastery. He should leave naked with ashes thrown on him. He should not settle in the same area." 155

Even more detailed is the account given in a recently written history of Tsurpu monastery. The author here reconstructs the chayik that was in use in his monastery before it went missing:

If something occurs that necessitates someone being expelled from the monastery's community, the chant master and the disciplinarian report the culprit to the treasury of the monastic residency to which he belongs. The treasury then dresses him in white. It is appropriate that he gets a punishment in front of everyone consisting of two hundred lashes of the whip, without protesting. He then needs to give, as an offering, a communal tea-round for the assembly of monks, which can be elaborate, average, or limited, as well as scarves for the throne. He then is again placed among the ranks of the menial servants, ${ }^{156}$ clerks, and taxpayers ${ }^{157}$ of the person who was lord when he was a layperson. Whether he is taxed or not is generally decided upon, depending on how he has been punished and the gravity of his offense. ${ }^{158}$

Here the monk who breaks his vows is suitably "laicized," punished physically and financially, and returned as a subject to his previous "lord." The passage that follows elaborates on what vows were broken. The text then discusses what happens to the girl who caused the monk's downfall:

The girl also needs to give two communal tea-rounds, as a confession to the assembly of monks, either elaborate or limited. According to the earlier $b \mathrm{Ca}^{\prime} \mathrm{gsal},{ }^{159}$ there was a custom of giving the girl two hundred lashings with the whip as a punishment, but after some time this went out of practice and it was substituted by the punishment of offering communal tea-rounds and by giving beautiful and expensive materials for a throne, pillar decorations or offering-materials and the like, acquired by honest means. Withdrawing her from the community ${ }^{160}$ also occurred, making an example [of her], regardless of her social status. In the place of each lash of the whip one 
kilogram ${ }^{161}$ of gathered wood had to be given, and two hundred kilograms of wood then needed to be offered to the general assembly of monks-this is what it said in the monastic guidelines. Having consulted with various guiding materials, things differed according to the specifics of the personal inclinations of the person in charge. The custom was that the treasury decided on either a heavy or a light punishment that was fitting, making sure that it would not reoccur in the future. ${ }^{162}$

Another instance that mentions the female party getting punished can be found in a chayik written for another Kagyü monastery. In this chayik for the Sikkimese Phodang (Pho ldang) monastery from the eighteenth century, it is suggested that the woman had to be punished by making a confession and giving offerings, similar to those of the monk. She also had to vow not to reoffend. If the monk and the woman continued their practices, they needed to do the same types of confessions and in addition pay twenty-five coppers coins. ${ }^{163}$

Sometimes, even allowing the mere presence of women in the monastery was enough to get expelled - at least, according to the warning given in a text directed to the population of Sera monastery:

Even if it is one's own mother, she may not obtain permission to stay unless it is during the "Great Giving ceremony." 164 If there are women in the monastery without permission, then the one responsible along with his accomplices will be expelled and the instigators each have to carry out the punishment of one communal tea-round and five hundred prostrations. ${ }^{165}$

Breaking the vow of celibacy is the most commonly mentioned "defeat" in the monastic guidelines. ${ }^{166}$ While sometimes monastic guidelines took a more pragmatic approach toward sexual conduct, in particular in Himalayan regions, ${ }^{167}$ for a monk to have sex always was tantamount to a loss of vows. A monastic community then could decide either to let the person retake his vows or to expel him. It is important to note that many other, and I dare say most, monastic guidelines-if they mention sexual conduct at all-do not take a tolerant stance with regard to issues of celibacy. To cite an example from the guidelines for Mindröl Ling monastery, written in 1698: "When someone is suspected of having had intercourse, he needs to be investigated and if it is found to be true, he is to be expelled under the sound of the very loud gandi. Even if his [case] seems to have supporters, it needs to be put an end to, for it has been determined that it was 'the first pāräjika."'168

A recurring myth, upheld by scholars even today, is that celibacy was only enforced in Geluk monasteries and that the attitudes toward sex in other institutions were more laissez-faire. ${ }^{169}$ While it is not possible to make claims on the actual practices of these non-Geluk monastic institutions, on the basis of the textual sources at hand it can be stated in no uncertain terms that on the level of monastic policy and ideology, sexual conduct was never simply tolerated. In fact, the emphasis on celibacy is found as often in non-Geluk monastic guidelines as it is in the Geluk ones. Thus, the notion that monastic institutions other than Geluk 
monasteries displayed a general, or even ideological, disregard for upholding the vow of celibacy needs to be put to bed once and for all.

Another set of guidelines for a Nyingma monastery, this time for Tengpoche from 1918, is equally intolerant of vow breakers:

As soon as a defeat of the four roots has occurred, the person who has broken his promise to his lama is expelled under the sound of the gandi. Not being allowed to leave behind even his boot, ${ }^{170}$ he has to survive in the [lay] community himself and in accordance with state law. ${ }^{171}$

The guidelines written in 1938 for Dophü Chökhor Ling give a reason why these monks may no longer stay at the monastery: "A dge tshul or dge slong, however good he is, who has transgressed the four roots should be expelled, as he can no longer partake in either Dharma or material goods together with the Sangha."172

Regularly, the monastic guidelines imply that monks who break their vows may not take their material wealth with them. The South Monastery of Sakya did not allow the expelled monk to take his possessions with him, and his things would be passed on to a monk relative in the same monastery. In other places in the vicinity of Sakya, however, an ex-monk could take his things, provided he admitted his transgression and offered the monk community a communal tea-round. The monk who tried to hide his faults, however, would be entirely dispossessed. ${ }^{173}$

Naturally, it was not just breaking the vow of celibacy that was punished by expulsion. The chayik for Jampa Ling from 1927 notes the range of "crimes" that could possibly result in getting sent away:

When there is someone who has been stained by the faults of the four roots and alcohol, by for example having hurt [another] by stones, knives, and weapons, then the wrongdoer gets expelled without chance for appeal. ${ }^{174}$ After an assessment of the severity of the misdeeds he is punished by the lama and the officials with, for example, a communal tea-round by general rule or by being returned to lay life. And when the monastery has done its task for the general benefit independently, the general populace should then take [this] layperson as their responsibility. ${ }^{175}$

As mentioned previously in this chapter, violence was a problem in many monasteries throughout the ages. A teacher at the Drigung monastic college in India acknowledges that sometimes this type of violence still occurs.

If weapons, like knives, are involved, the monks get expelled. One has to always look at the circumstances, though. If someone gets into trouble again and again and when this is addressed he talks back to the teacher, then sometimes there is no way other than to expel him. Most of the time, however, someone like that leaves before he can get expelled. Once they are expelled they cannot come back. ${ }^{176}$

The chayik written by the Fifth Dalai Lama for Gongra Ngesang Dorje Ling lists intercourse, killing a person, stealing something of value, and hurting others as crimes that could lead to expulsion. The text also adds the smoking of tobacco 
and stealthily using the Sangha's general possessions for oneself. ${ }^{177}$ The latter issue of using the monastic community's possessions is also seen by the author of the chayik for Dophü Chökhor Ling written in 1938 as a reason to send a monk away: "If it transpires that a person has taken additional donations and salary, he will be expelled." ${ }^{778}$

\section{REENTERING THE MONASTERY}

So far, the technical term "expulsion" has been used to translate the Tibetan gnas dbyung. But what did this entail? Was a monk permanently expelled, banned from the monastery, or was there a way to make amends? Clarke has criticized the translation of "expulsion" for the Sanskrit asamvāsa. He argues that, according to the Vinayas, being no longer in communion-the actual meaning of asamvāsa-did not equate to expulsion. ${ }^{179}$ It is argued that in the Indian case it was not entirely clear what happened to a monk who committed a pāräjika. The examples given above, however, make it rather clear that in the Tibetan context, gnas dbyung meant becoming dislocated, being made to physically leave the monastic grounds rather than simply to no longer be in communion. ${ }^{180}$ As far as I am aware, the more Vinayic gnas par mi bya ba, which is a translation for asamvāsa, is not used in the chayik. Thus, while it is clear that expulsion was a punishment given to Tibetan monks, what happens after that is not.

Clarke counters the widespread notion that monks who, for example, had sex were "immediately and irrevocably expelled from the Buddhist order." ${ }^{181}$ He argues that this equation of sex with permanent expulsion has been created by "modern commentators," but is not supported by Indian Buddhist monastic law codes. ${ }^{182}$ In the Tibetan situation, we have seen that the punishment of expulsion, be it for a pāräjika or otherwise, was not always immediate. Rather, many monastic guidelines recommend a process of careful investigation. Furthermore, in some cases there was a way back to the monastery. While many guidelines state that monks who have been expelled elsewhere may not be allowed into the monastery, ${ }^{183}$ the return to monkhood was technically not impossible. This is in line with the fact that all Vinayas, except the Pāli Vinaya, allow men to remain members of the monastic community "if truly remorseful." 184

An example of a chayik in which reentering the monastery appeared possible is the set of monastic guidelines for the Sikkimese Phodang monastery by the Fourteenth Karmapa (Theg mchog rdo rje, 1797-1868?), composed in 1846. In this text, he-possibly taking the specific circumstances of Sikkim into accountmentions inmates of the monastery who have had sex. They can, he states, remain in or perhaps "reenter" the monastery and the monastic group to which they belonged. This can only take place after the person in question has made extensive reparations in the form of offerings to the Three Jewels and the monastic community, has confessed his faults, has made prostrations in the assembly, and has 
"renewed his seat" 185 in the assembly. What is made clear is that the monk, having had intercourse, effectively loses his monastic vows and therefore has to retake them. ${ }^{186}$ However, this does not deny the offender future monkhood. Risley, who may have had direct or indirect access to a chayik in use in "Pemiongchi" (Padma yang rtse) monastery in the late nineteenth century, makes a similar observation in his Gazetteer of Sikhim:

The regulation which is most frequently violated is that of celibacy; but in most of the institutions other than Pemiongchi celibacy is not observed. Should it be proved that a Pemiongchi monk consorts with women, he will be expelled by a chapter, unless it be his first offence and he prays publicly for forgiveness, and then is awarded some penance and pays a fine of 180 rupees according to the rules of the lChags-yig [sic: chayik]. ${ }^{187} \mathrm{He}$ must also pay over again the entrance fees and presents as before. ${ }^{188}$

Clearly then, the Tibetan monastic guidelines cited above seem to follow Clarke's findings regarding Vinaya, in that they imply that sex does not necessarily lead to expulsion, and that retaking the vows was possible. Pelyul Darthang monastery's guidelines show a willingness to allow even murderers back among the ranks:

Those who have been dismissed from the yellow ranks, such as those who have started a family, have killed a man, who have done things like robbing and deceiving people by, for example, taking their wealth, or otherwise, those who have insulted others by having caused fights, arguments, and strife, when they reenter the assembly, may only do so after having developed the preliminaries, having been engaged in various practice sessions, and having confessed. ${ }^{189}$

As indicated above, the people who reenter are, in terms of their vows, new monks and thus need to take a junior position:

When they do enter the assembly, they sit in the lowest row, and not in the higher rows without having taken vows. When they enter the assembly they need to have quit their previous bad behavior. If not, then they need to be dismissed from the rows of the assembly and unless they are punished suitably, they may not be allowed back in just like that. ${ }^{190}$

The text furthermore states that these people, even if they are allowed into the assembly, may not be promoted to lama, chant master, or teacher of ritual dance. ${ }^{191}$ This effectively means that monks "with a past" could not occupy positions in which they had to fulfill an exemplary or public function.

\section{STATE INVOLVEMENT IN MONASTIC LEGAL PROCESSES}

As we have seen above, the monastic guidelines occasionally recommend handing over a monastic offender to the "secular authorities." Particularly regarding the 
issue of murder, the case is almost always referred to "secular law" - which may have meant different things at different times, but always indicated a legal authority outside the monastery. ${ }^{192}$ In the same way, Goldstein comments that "murder cases were always considered to be under the jurisdiction of the government; the government retained ultimate control over the taking of human life." ${ }^{193}$ Thus when rogue monks were involved in fights that ended in death, there would have been both monastic and secular punishment. ${ }^{194}$ According to the Mindröl Ling guidelines all crimes that fell under general law needed to be reported to the headman at the estate. ${ }^{195}$ It is unfortunately not specified what crimes these were and what was to happen next.

We do know that in the early twentieth century, it was not only murder for which monks were punished under secular law. Bell reports that the Drepung ringleaders who tried to start a rebellion against the Tibetan government were beaten, expelled, and subsequently punished under secular law. ${ }^{196}$ Furthermore, a photograph taken during Bell's mission to Lhasa in 1920-21 shows a Drepung monk with his head in stocks. The note accompanying the picture states that this was his punishment for forging currency notes. ${ }^{197}$ Naturally, a close relationship between the monastery and the central government made the threat of secular punishments more likely.

A set of guidelines written in 1920 and directed to the whole of Sera monasterywhich, of all large monasteries, was physically the closest to the Ganden Phodrang government in Lhasa-attempts to add an extra layer of state control: "People who have the responsibilities of scholars but do not behave accordingly, who disgrace the Dharma or the practitioners of the Dharma, should be suppressed according to secular law, without relenting." ${ }^{198}$ Elsewhere in the same text there is a relatively long section on the occurrence of people in the vicinity posing as monks, who were behaving badly. ${ }^{199}$ The work states that it was not allowed to count these people among the Sangha:

And if there are still people who stay on pretending, like summer grass pretends to be a winter worm and a rabbit pretends to be a rock, then the officials who have agreed to let them stay may not act as if they did not know, because they themselves were in charge. After they [the officials] have been expelled, they are punished heavily for this according to secular law, and then they are banished. ${ }^{200}$

Here, it is not just the people who pretend to be monks who get punished according to state law, but also those monastic officials who allow them to stay, in all likelihood accepting bribes in return for this favor. This shows that having these people live in the vicinity was probably seen as a security threat. Sera monastery's great power also meant being responsible for keeping imposters at bay.

The "purification" of the Sangha was thus, contrary to what occurred in, for example, Sri Lanka, Thailand, and occasionally even in Mongolia, ${ }^{201}$ not directly 
the responsibility of the state but of the monasteries that were guided and, perhaps, goaded by the ruler. This was only the case when this leader was in a position to assert himself, for example during the rule of the Thirteenth Dalai Lama. In light of the contents of a number of monastic guidelines, the picture of Tibet as a centralized state ruled by a theocratic government in Lhasa is not convincing. ${ }^{202}$ Monasteries were, for the most part, self-regulating bodies. The threat of secular law was merely a last resort. This is further exemplified by Jamgön Mipham (1846-1912), who wrote A Treatise on Ethics for Kings: An Ornament for Rulers for a prince of the kingdom of Dergé:

However, in this degenerate age,

There are many monks who are exceedingly unruly.

When they cannot be disciplined

Through the sangha council's religious procedures,

Then the king needs to do this. ${ }^{203}$

Elsewhere in the same work, the author stresses that the ruler should leave the punishment of monks who have transgressed their vows to the discretion of the monastic authorities. ${ }^{204}$

More research is needed to establish the relationship between secular and monastic laws in Tibetan culture, in particular with regard to the influence of monastic rulings and punishments apparent in governmental regulations. An interesting example of this is the description of how government officials were punished for faulty behavior. They were to make prostrations, and if their position had become untenable, they were made to wear white clothes and driven out of the premises on a donkey. ${ }^{205}$ This is more than vaguely reminiscent of how monks were expelled from their monasteries according to the descriptions given above.

Another noteworthy issue is that of the legal status of the monastery as a safe haven for others. In Sri Lanka, in the tenth century, wanted criminals could seek refuge in the monasteries from where they could not be extradited. During that time, the king had transferred the judicial authority he previously enjoyed over the property of the Sangha to the monastery, allowing and requiring the monasteries to manage their own property in all aspects. ${ }^{206}$ Several remote monasteries in eighth-century China exercised a similar level of autonomy: they seem to have regularly sheltered less savory characters. ${ }^{207}$ Considering that certain Vinaya rules, such as that of not allowing wanted criminals to become monks, appear to have been created to appease the secular authorities, it is puzzling that monasteries would offer amnesty to these people, to say the least.

One does not expect the Tibetan monastic guidelines to offer wanted criminals an escape from justice, but the monastic guidelines for Gongra Ngesang Dorje Ling contain some surprising information. This text was written by the Fifth Dalai Lama for a monastery that had previously sided with those who opposed the 
Mongolian troops that had helped the Dalai Lama gain temporal power. While the text does not call on the monastic authorities to undermine state law, it declares: "When there are 'criminals' who have broken other [people's] laws and ask for refuge, one should be of benefit." ${ }^{208}$ The text, unfortunately, offers no context for this statement, making it difficult to explain. What can be noted from this remark, however, is that in the late seventeenth century even the highest political authority, the Dalai Lama himself, was aware that his government did not have the power to submit all wrongdoers to justice, thereby acknowledging the legal plurality that Tibetan areas had known for centuries.

While state interference in monastic affairs has clear historical precedent, current governmental regulations in Tibetan areas are perceived by monks as going against monastic rule, ${ }^{209}$ in particular with regard to the expulsion of monks. The age limits set for monks entering the monastery and the appointment of those to high positions serve as further examples. With the exception of murder, treason, and forgery, on the whole, the historical monastic guidelines demonstrate that monasteries themselves had the authority to make these types of decisions. ${ }^{210}$ This is exemplified by the fact that the individual monastic guidelines contain such a wide range of regulations regarding legal issues.

\section{MONASTIC BUDDHIST NOTIONS OF JUSTICE}

The distinctions between monastic law and secular law, which need further scrutiny, are occasionally clearly demarcated in the text and at other instances left unclear. Both the Dharma and law are concerned with maintaining a balance of power, ultimately bringing about wide-reaching effects, the primary of which is the happiness and welfare of sentient beings. A Bhutanese law code lays bare the connections that are less visible in the monastic guidelines: "Well-being in all the lands depends on the state law being in accord with the Dharma. The prophecy of the Dharma-cakravartin on governing the state can be truly seen in the Teachings of the Buddha; other than that what else is there?"211

In many ways, law may be seen as promising justice and social order, but within Tibetan society there seems to have been awareness that secular law is not separable from cosmic effects and that social order thus is not dependent on this type of justice alone. The passage from monastic guidelines from 1918 cited earlier, connecting the purity of the Sangha, the happiness of the land, and the adherence to the sixteen pure "human rules" further illustrates this point.

Monks, we know from other sources, were part of the legal system in Tibet, but the influence of monastic ideology on legal structures has not yet been established, although there are indications suggesting that this influence was substantial. ${ }^{212}$ The monastic guidelines that have stronger links to the state authorities tend to show more involvement in the execution of justice, but on the whole most monasteries, 
regardless of their affiliation, demonstrate an awareness of both their rights and responsibilities. Meting out punishments was one of those responsibilities, which clearly never had "a return to inner morality" as an objective. ${ }^{213}$ Rather, according to the texts, penalties served "to make an example" of the perpetrator, preventing others from doing the same in the future. Failing to carry out that duty of punishing led to further punishment. This may have some correspondences to descriptions of the ideal behavior of Bodhisattvas that feature in some Indic Buddhist texts. In the Bodhisattvabhumi, for example, the Bodhisattva is not simply required to correct the behavior of others by punishing: he commits a fault if he neglects to do so. ${ }^{214}$ The emphasis in the monastic guidelines also lies on a fair but pragmatic application of the rules: justice is not done at all costs. It should be noted that karma, the law of cause and effect, is not engaged at any level in the monastic guidelines.

Notions of fairness and justice-if at all mentioned in Buddhist Studies literature-are often addressed in terms of the workings of karma. Tempting though it may be to then conclude that for Buddhists the natural law of karma can be equated with all types of justice, such as social, punitive, and conciliatory justice, it is clearly mistaken to conflate a doctrinal issue with actual practice. Collins argues this point in the following way:

In the European-Christian case, everyone is intimately aware, as a matter of day-byday experience, of the continuous and changing way ideals and the Lebenswelt coexist, of their sometimes stark, sometimes subtle and nuanced relations of contradiction, complementary opposition, or agreement; and so it is easy to see immediately that such an abstract and simplistic deduction from universal and ideal premisesGod will punish, therefore there should be no need for law-is quite inappropriate for historical understanding, however admirable the ideals may (or may not) be. The Buddhist case is just the same. ${ }^{215}$

The way in which monastic law is understood by monastic authors themselves is rather similar, if not identical to law outside of the Tibetan monastery. Laws-and by extension justice-serve to secure social order, making it "particularly effective as an instrument of government." ${ }^{216}$ In the Tibetan societies, where the government has traditionally been a symbolically prominent yet functionally absent factor, the distinctions between law and custom, ${ }^{217}$ or law and morality, are less easily made. ${ }^{218}$ Buddhist morality and secular law ultimately are both "normative social practices that set standards for desirable behavior and proclaim symbolic expressions of social values.".219

Religion is often seen as providing a means of social control, which implies "a system of rewards and punishments, either internalized during socialization or externally supplied by institutions, or both." ${ }^{220}$ The monastic guidelines emphasize externally supplied punishments, but not because karma is not part of the equation, or not believed in. In other words, the goal of promoting justice-by, for 
example, making a monk do prostrations-is not in order to allow him to accumulate merit, thereby cancelling out his misdeeds. Rather, it serves to keep the peace, to restore the reputation, to promote a sense of cohesion, and to strengthen the identity of the monastic community. While Buddhism is regularly both praised and vilified for its individualist tendencies, on a monastic level the execution of justice was a communal exercise and karma played only a minor part. This notion of justice as being communal and for the sake of social order is strongly connected to the perceived responsibility of the monastic community in society. 